I N T ER N ATIONAL MONETARY FUND

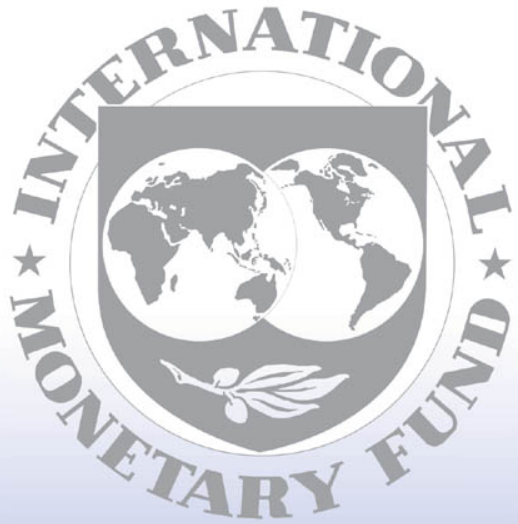

Staff

Country

Reports 


\title{
Mauritius: Financial System Stability Assessment-Update
}

This update to the Financial System Stability Assessment on Mauritius was prepared by a staff team of the International Monetary Fund as background documentation for the periodic consultation with the member country. It is based on the information available at the time it was completed on April 20, 2007. The views expressed in this document are those of the staff team and do not necessarily reflect the views of the government of Mauritius or the Executive Board of the IMF.

The policy of publication of staff reports and other documents by the IMF allows for the deletion of market-sensitive information.

\author{
Copies of this report are available to the public from \\ International Monetary Fund • Publication Services \\ 700 19th Street, N.W. • Washington, D.C. 20431 \\ Telephone: (202) 6237430 • Telefax: (202) 6237201 \\ E-mail: publications@imf.org • Internet: http://www.imf.org \\ Price: $\$ 18.00$ a copy

\section{International Monetary Fund \\ Washington, D.C.}


This page intentionally left blank 


\title{
INTERNATIONAL MONETARY FUND
}

\section{MAURITIUS}

\section{Financial System Stability Assessment Update}

\author{
Prepared by the Monetary and Capital Markets and African Departments \\ Approved by Jaime Caruana and Abdoulaye Bio-Tchané
}

April 20, 2007

\begin{abstract}
This report is based on the work of a joint IMF/World Bank Financial Sector Assessment Update mission to Mauritius during February 6-20, 2007. The mission comprised Ann Rennie (Team Leader, World Bank), Mary Zephirin (Deputy Team Leader, IMF), Patrick Honohan, Lars Jessen, Dimitri Vittas, and Cally Jordan (all World Bank); Kiran Sastry (IMF/MCM), Alfredo Bello, Keith Bell, and Christo Wiese (all IMF consultants), and Pauline Ravalisoamampianina (Administrative Assistant, World Bank). An AML/CFT assessment is planned for September 2007.

The key findings of the FSAP Update are:
\end{abstract}

- Institutional shortcomings have delayed or weakened the implementation of significant reforms undertaken since the 2002-03 FSAP. The staffing, administration, and organization of the regulatory agencies need further strengthening.

- The Mauritian financial system has been resilient to recent economic shocks, and banks have adequate capital buffers against a range of shocks to their credit portfolios and liquidity positions. In high stress situations, however, individual banks may face difficulties. More advanced risk assessment methods, including stress testing, would be a valuable addition to the supervisors' planning tools and capacity.

- Infrastructural reforms have improved the business environment but there are several areas, such as insolvency rules, monetary policy, and debt management, where further steps should be given high priority.

The main author of this report is Mary Zephirin, with contributions from the rest of the FSAP team.

FSAPs are designed to assess the stability of the financial system as a whole and not that of individual institutions. They have been developed to help countries identify and remedy weaknesses in their financial sector structure, thereby enhancing their resilience to macroeconomic shocks and cross-border contagion. FSAPs do not cover risks that are specific to individual institutions such as asset quality, operational or legal risks, or fraud. 


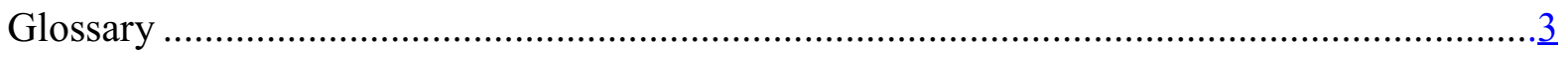

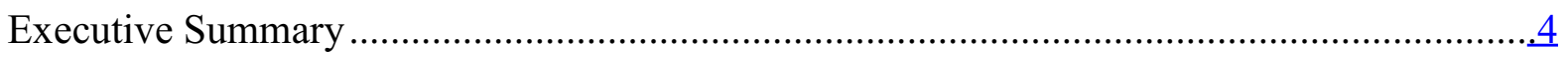

Summary of Principal Recommendations ………………................................................

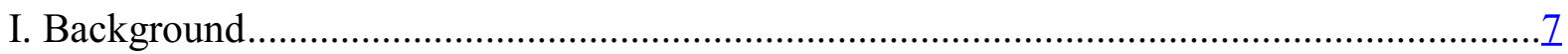

A. Macroeconomic Context ................................................................................

B. Conclusions and Recommendations of the 2002-03 FSAP ……………………....

II. Financial System: Structure and Performance ……….....................................................

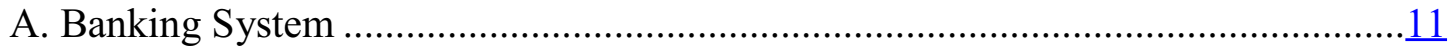

B. Other Financial Institutions and Markets ............................................................16

III. Financial Sector Supervision and Regulation .............................................................

A. Regulatory Reforms and Developments .............................................................18

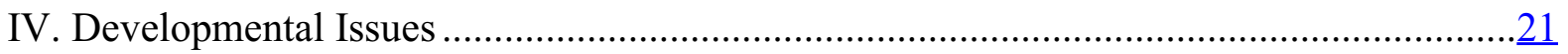

A. Infrastructural Developments..........................................................................21

B. Access to Financial Services ...........................................................................22

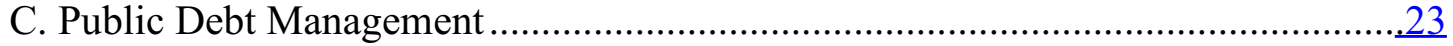

D. Monetary Policy Operational Framework..............................................................24

Tables

1. Selected Macroeconomic Indicators, 2000/01-2005/06 ..................................................

2. Financial System Structure ........................................................................................10

3. Asset Composition and Performance Measures by Bank Type, 2006 ................................11

4. Financial Soundness Indicators for the Banking Sector, 2002-2006 ….............................13

5. Recommended Action Plan to Improve Compliance with the Basel Core Principles..........33

Box

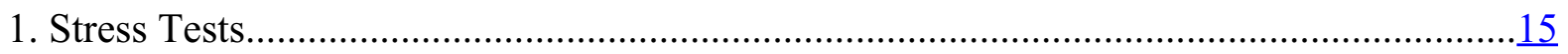

Appendixes

I. Status of Implementation of Key Recommendations of the 2002-03 FSAP................26

II. Summary Assessment of Compliance with the Basel Core Principles for Effective

Banking Supervision ....................................................................................28 


\section{GLOSSARY}

BA

BOM

BOMA

CAR

DTAT

DBM

FIAML

FRA

FSC

FX

GBC

IA

MIPA

MHC

MOFED

MOU

NBFI

NPF

OECD

ROA

ROE

SA

SEM

SOE

TOT
Banking Act, 2004

Bank of Mauritius

Bank of Mauritius Act, 2004

capital adequacy ratio

double taxation avoidance treaty

Development Bank of Mauritius

Financial Intelligence and Anti-Money Laundering Act, 2002

Financial Reporting Act, 2004

Financial Services Commission

foreign exchange

Global Business Companies

Insurance Act, 2005

Mauritius Institute of Professional Accountants

Mauritian Housing Company

Ministry of Finance and Economic Development

memorandum of understanding

nonbank financial intermediary

National Pension Fund

Organization of Economic Cooperation and Development

return on assets

return on equity

Securities Act, 2005

Stock Exchange of Mauritius

state-owned enterprises

terms of trade 


\section{EXECUTIVE SUMMARY}

Mauritius's financial sector has shown resilience in the face of recent setbacks to the economy. Financial institutions are in general well capitalized and profitable, and hence less vulnerable to the credit risks that may be triggered by shocks to leading sectors. The challenge will be to maintain the system's strength in the context of economic restructuring and a lower growth environment, high domestic public debt, and fiscal consolidation. Meeting this challenge will place an even greater premium on effective oversight and institutional strengthening.

\section{The mission recommends a number of issues for attention:}

- $\quad$ Significant policy reforms have been undertaken since the 2002-03 FSAP to strengthen the financial infrastructure, but institutional weaknesses have delayed their full implementation. Legal and regulatory reforms in financial reporting, corporate governance, the insolvency regime, the tax structure, and public debt management have improved corporate governance and financial disclosure in large private companies and reduced distortions. However, the authorities will need to avoid further delays in establishing key implementing bodies, since these have limited progress in the areas of financial reporting, monetary policy, and supervision.

- $\quad$ Progress has been made in financial regulation and supervision, but organizational weaknesses and legislative delays have limited its scope. The financial reforms entail substantial legislative change, the volume of which has strained capacity, delaying the coming into force of insurance, pensions, securities, and sections of banking legislation. In addition, staff shortages and training needs impede supervision by the regulatory bodies - the Bank of Mauritius (BOM) and the Financial Services Commission (FSC).

- $\quad$ The profitability and capitalization of the banks provide cushions against shocks, but regulators should improve their supervision of risk management. The banking system is highly concentrated, and its core (the largest, dominant banks) would appear to be fairly robust to credit and liquidity shocks. However, smaller banks would be challenged to meet the regulatory capital requirement in the event of stress. Against this background, there is a need to increase supervisory capacity to evaluate risks, including by reviewing bank data more frequently and by undertaking stress tests.

- The regulators' ability and capacity to take effective prompt corrective action to deal with distressed financial institutions should be enhanced. Inability to intervene in an urgent case could result in disorderly exit of institutions, which could adversely affect confidence and Mauritius' reputation as a financial center. It will be 
important to ensure enactment of relevant sections of the Banking Act 2004, and of the new Insurance (IA) and Securities (SA) Acts, whose provisions should help avoid the problem of regulatory forbearance.

- The short maturity structure of Mauritius's high domestic public debt poses significant interest rate and budgetary risks. The core issue is the need for fiscal consolidation, but, in addition, finalization of the draft debt management strategy is needed to provide a framework for extending the maturity structure of the debt, to improve the planning of government borrowing, and to contribute to the deepening of the debt market.

- An analytical foundation for monetary policy will be essential for the authorities to control inflation. While the operational aspects of the monetary policy framework are in place, analysis of the economic relations that underpin monetary policy needs to be advanced.

- Priority should be placed on strengthening the independence, administration, and manpower planning of the regulatory agencies and other oversight bodies. The credibility and effectiveness of the regulatory agencies depend critically on a sound legal and administrative basis for their independence, as well as care by the authorities to avoid giving the appearance of interference.

Although the financial sector is well developed and access is high, there are a number of areas where policies could assist in further strengthening the effectiveness of bank and nonbank intermediation. In particular, there is scope to further upgrade SOE governance and to improve oversight of insolvency practitioners. Moreover, an extension of the coverage of the Credit Information Bureau could improve access to credit by small borrowers. Finally, steps to improve government debt management and to deepen the market for longer term securities appear warranted, both to help address debt sustainability concerns but also to improve the private sector's access to financing. 


\section{Summary of Principal Recommendations}

\begin{tabular}{|c|c|}
\hline Within One Year & Within Two Years and Ongoing \\
\hline \multicolumn{2}{|l|}{ Regulatory agencies } \\
\hline $\begin{array}{l}\text { Improve cooperation between the BOM and the FSC by } \\
\text { activating, and expanding the scope of the December } 2002 \mathrm{MOU} \\
\text { to ensure effective supervision of financial conglomerates. }\end{array}$ & $\begin{array}{l}\text { Review governance of FSC to ensure greater statutory } \\
\text { independence. }\end{array}$ \\
\hline $\begin{array}{l}\text { Fully operationalize the Financial Reporting Council which } \\
\text { enforces compliance with accounting and auditing standards and } \\
\text { regulates audits. }\end{array}$ & $\begin{array}{l}\text { Review BOM's organization and administration to } \\
\text { improve human resource management, and the capacity } \\
\text { and analytical support for policy making. }\end{array}$ \\
\hline \multicolumn{2}{|l|}{$\begin{array}{l}\text { Adopt manpower plans for the BOM and FSC with strong } \\
\text { emphasis on training and capacity building, and immediate } \\
\text { attention to filling vacant positions with qualified officials. }\end{array}$} \\
\hline \multicolumn{2}{|l|}{ Insurance } \\
\hline \multirow[t]{2}{*}{$\begin{array}{l}\text { Finalize implementing regulations, including risk-based solvency } \\
\text { rules, and proclaim the IA. }\end{array}$} & $\begin{array}{l}\text { Develop early warning system and strengthen } \\
\text { intervention action when insurance companies adopt } \\
\text { imprudent practices. }\end{array}$ \\
\hline & $\begin{array}{l}\text { Strengthen the program of on-site inspections by } \\
\text { focusing on assessing adequacy of corporate } \\
\text { governance, internal controls, and risk management. }\end{array}$ \\
\hline \multicolumn{2}{|l|}{ Pensions } \\
\hline $\begin{array}{l}\text { Finalize new private occupational pension bill and take steps to } \\
\text { enact and proclaim it. }\end{array}$ & $\begin{array}{l}\text { Upgrade investment management of the NPF by } \\
\text { ensuring the independence of its new Investment } \\
\text { Committee and appointing experienced professionals } \\
\text { with appropriate skills. }\end{array}$ \\
\hline \multicolumn{2}{|l|}{ Corporate environment and securities market } \\
\hline Complete implementing regulations and proclaim the SA. & $\begin{array}{l}\text { Develop effective supervision of collective investment } \\
\text { Schemes. }\end{array}$ \\
\hline Prepare, enact, and proclaim the new Insolvency Act. & $\begin{array}{l}\text { Ensure that the new self-regulatory function of the } \\
\text { Stock Exchange of Mauritius (SEM) is implemented } \\
\text { through procedures that avoid potential conflict with } \\
\text { shareholder interests. }\end{array}$ \\
\hline \multicolumn{2}{|l|}{ Money and public debt markets } \\
\hline \multicolumn{2}{|l|}{$\begin{array}{l}\text { Activate the Monetary Policy Committee to advise on monetary } \\
\text { policy (planned for April, 2007) }\end{array}$} \\
\hline \multicolumn{2}{|l|}{$\begin{array}{l}\text { Review money market operations and consider potential measures } \\
\text { to optimize them. }\end{array}$} \\
\hline $\begin{array}{l}\text { Finalize public debt management strategy and enhance the } \\
\text { primary market by, for e.g., publishing a borrowing calendar, } \\
\text { concentrating borrowing in fewer securities }\end{array}$ & \\
\hline
\end{tabular}




\section{BACKGROUND}

\section{A. Macroeconomic Context ${ }^{1}$}

1. After two decades of solid growth, Mauritius's economy has slowed as a result of a terms of trade (TOT) deterioration. The loss of trade preferences following the expiration of the Multifiber Agreement, and decreases in the European Union's sugar import prices over the period 2006-10, and higher oil prices, have resulted in a permanent deterioration in the terms of trade. ${ }^{2}$ They, along with high fiscal deficits and slow adjustments in consumption, have increased the current account deficit and external vulnerability (see Table 1).

2. The 2006/07 budget initiated reforms to address structural constraints, and there are signs of economic recovery. The authorities have begun fiscal consolidation, simplified the tax system, removed some subsidies, and liberalized trade. Strong service sector activity and slowing job losses in the textile sector have helped revive growth. Labor market reform is also planned.

3. Macroeconomic imbalances remain and continued strong reform efforts are needed. Headline inflation is expected to decline once the effects of the budget (subsidy removal) are past. High public debt could increase interest rates, crowd out private investment, and retard external adjustment.

4. Depreciation in the exchange rate has helped adjustment to the TOT shock, but continued flexibility will be important to maintain competitiveness. The nominal rate is market-determined (a managed float) and staff estimates presently suggest that the real effective exchange rate is just above its equilibrium level, and going forward exchange rate intervention should be limited to smoothing excess volatility.

5. There are both upside and downside risks to the outlook. On the upside, reforms to improve competitiveness could provide a further boost to the service sector, and improvements in monetary policy implementation, improved risk monitoring by both the financial institutions and their regulators, as well as improved debt management, would also help. However, the possibility of higher oil prices or higher-than-expected fiscal deficits could pose downside risks.

\footnotetext{
${ }^{1}$ For more details see the Staff Report for the 2007 Article IV Consultation, IMF Country Report 07/192.

${ }^{2}$ See Assessment Letter in the Context of the Aid for Trade Initiative, September 9, 2006, (www.imf.org).
} 
Table 1. Mauritius: Selected Macroeconomic Indicators, 2000/01-2005/06 1/

\begin{tabular}{|c|c|c|c|c|c|c|}
\hline & $2000 / 01$ & $2001 / 02$ & $2002 / 03$ & $2003 / 04$ & $2004 / 05$ & $2005 / 06$ \\
\hline \multicolumn{7}{|l|}{ Real Sector (in percent, unless otherwise indicated) } \\
\hline Real GDP growth & 8.2 & 4.3 & 2.5 & 4.5 & 3.0 & 3.7 \\
\hline GDP at market prices (in millions of rupees) & 125,220 & 137,119 & 149,893 & 166,061 & 181,025 & 195,441 \\
\hline GDP deflator (change in percent) & 4.6 & 6.5 & 5.9 & 5.7 & 4.9 & 5.4 \\
\hline Consumer price index (change in period average) & 4.4 & 6.3 & 5.1 & 3.9 & 5.6 & 5.1 \\
\hline Unemployment rate (in percent, end-year) & 6.9 & 7.3 & 7.7 & 8.5 & 9.0 & 9.5 \\
\hline \multicolumn{7}{|l|}{ Monetary and credit data (annual change in percent) } \\
\hline Money (M1) & 14.9 & 19.1 & 15.2 & 22.3 & 6.2 & 12.7 \\
\hline Broad money (M2) & 9.9 & 13.0 & 11.7 & 14.4 & 8.5 & 11.2 \\
\hline Domestic credit & 6.5 & 7.9 & 7.6 & 20.5 & 11.3 & 13.0 \\
\hline Yield on 91-day treasury bills $2 /$ & 9.7 & 9.2 & 8.4 & 4.7 & 5.1 & 6.4 \\
\hline Yield on 364-day treasury bills $2 /$ & 11.9 & 10.9 & 9.7 & 7.1 & 6.2 & 7.4 \\
\hline Prime lending rate of commercial banks $3 /$ & $10.0-12.2$ & $10.0-11.7$ & $8.7-11.2$ & $7.5-9.2$ & $7.5-8.7$ & $8.00-10.2$ \\
\hline Interest rate (one-year term deposits, in percent) 4/ & $6.5-11.6$ & $6.5-12.0$ & $5.25-11.5$ & $2.7-10.5$ & $2.7-9.7$ & $3.0-9.4$ \\
\hline Stock market index (percent change, end of period) & -5.7 & -7.3 & 35.7 & 34.6 & 10.4 & 16.3 \\
\hline \multicolumn{7}{|l|}{ Public finances (in percent of GDP at market prices) } \\
\hline Central government overall balance (including grants) & -6.7 & -6.1 & -6.2 & -5.4 & -5.0 & -5.3 \\
\hline Central government domestic debt & 42.6 & 48.9 & 57.6 & 51.2 & 53.4 & 53.6 \\
\hline Central government external debt & 5.7 & 6.4 & 6.1 & 5.1 & 5.1 & 4.4 \\
\hline Public sector debt $5 /$ & 63.9 & 70.2 & 81.3 & 70.5 & 71.7 & 71.3 \\
\hline \multicolumn{7}{|l|}{$\begin{array}{l}\text { External sector (levels in millions of U.S. dollars, } \\
\text { unless otherwise indicated) }\end{array}$} \\
\hline Rupees per U.S. dollar (end of period) & 29.2 & 30.0 & 28.7 & 28.0 & 29.4 & 30.9 \\
\hline Trade balance & -252.1 & -205.2 & -315.0 & -381.1 & -710.2 & -844.2 \\
\hline Current account balance & 153.8 & 247.8 & 129.5 & 50.4 & -220.6 & -340.3 \\
\hline Current account balance (in percent of GDP) & 3.4 & 5.4 & 2.4 & 0.8 & -3.5 & -5.3 \\
\hline Foreign direct investment (net) & 196.7 & 48.5 & 64.1 & 35.1 & -31.0 & 19.0 \\
\hline Portfolio investment (net) & -138.5 & -19.9 & -22.4 & -27.1 & -11.3 & -55.2 \\
\hline Net international reserves of the Bank of Mauritius & 771.7 & 998.4 & $1,376.8$ & $1,542.1$ & $1,452.4$ & $1,373.1$ \\
\hline in months of prospective imports, c.i.f. & 4.8 & 6.2 & 7.3 & 7.5 & 6.1 & 5.0 \\
\hline Net international reserves of the banking system $6 /$ & $1,068.2$ & $1,334.2$ & $1,654.5$ & $1,750.9$ & $1,801.4$ & $1,987.1$ \\
\hline in months of prospective imports, c.i.f. & 6.7 & 8.2 & 8.8 & 8.5 & 7.5 & 7.3 \\
\hline Public sector external debt & 861.9 & 917.1 & 928.8 & 843.59 & 813.0 & 768.1 \\
\hline Banking sector external debt $7 /$ & 101.8 & 106.9 & 235.3 & 230.2 & $1,512.7$ & $2,552.8$ \\
\hline Debt-service ratio (in percent of exports of goods and & & & & & & \\
\hline services) & 9.7 & 8.5 & 8.0 & 6.5 & 6.5 & 7.0 \\
\hline Central bank foreign liabilities & 0.0 & 0.0 & 0.0 & 2.9 & 1.3 & 0.1 \\
\hline $\begin{array}{l}\text { External interest payments (in percent of exports of } \\
\text { goods and services } 8 /\end{array}$ & 0.6 & 0.3 & 0.3 & 0.3 & 0.2 & 3.2 \\
\hline Foreign currency long-term debt rating by Moody's & Baa2 & Baa2 & Baa2 & $\mathrm{Baa} 2$ & Baa2 & $\mathrm{Baa} 2$ \\
\hline
\end{tabular}

Sources: Bank of Mauritius (BOM); the Central Statistical Office (CSO); and IMF staff estimates.

$1 /$ Fiscal year from July to June.

2/ Weighted average for the year.

3/ Minimum and maximum observed during the year.

4/ Remaining maturities of one year or less.

$5 /$ Includes central and local government and parastatals

6/ With effect from June 2005, comprises the net foreign assets of banks, adjusted for transactions of Global Business License Holders.

7/ Prior to 2004/05, referred to former Category 1 Banks only. Effective 2004/05, refers to all banks.

8/ Effective 2005/06, includes interest payments of the banking sector. 


\section{B. Conclusions and Recommendations of the 2002-03 FSAP}

\section{The 2002-03 FSAP concluded the following:}

- Mauritius had a relatively large and well-developed financial system. Basic financial sector infrastructure, such as payment, securities trading and settlement systems, was modern and efficient, and access to financial services was high, with more than one bank account per capita.

- $\quad$ Short-term stability risks were modest. Stress tests indicated that a severe or prolonged downturn in economic activity in key sectors where bank exposure was significant could threaten bank solvency, though the system appeared resilient to all but very large shocks. The FSAP also recognized the risks associated with the erosion of trade preferences.

- The financial sector was found to be generally sound and profitable, but the dominance of a few major banks and the concentration of risks posed some systemic risks, and inhibited competition and innovation.

- The short maturity profile of domestic public debt exposed the government to considerable interest rate and roll-over risk.

Appendix 1 outlines the measures taken by the authorities to address key recommendations.

\section{Financial System: Structure and Performance}

7. Mauritius has a relatively well-developed financial system although, as is common in small countries, the securities markets are shallow. The system has grown significantly since the 2002 FSAP. Total banking assets are now some 300 percent of GDP as compared with 200 percent in 2002; in addition, the sharp distinction between offshore and domestic banking is no longer applicable — under the 2004 Banking Act (BA), licensing differences between domestic (Category 1) and offshore (Category 2) banks were removed and a single license was introduced from June 2005. Other elements of the financial sector are much smaller - insurance and pension sector assets are equivalent to some 50 percent of GDP and market capitalization about 80 percent of GDP. In addition to the banks, regulated nonbank deposit takers, comprising leasing companies and government-owned financial institutions, have assets equivalent to 15 percent of GDP (Table 2). 
Table 2. Mauritius: Financial System Structure

\begin{tabular}{|c|c|c|c|c|c|c|c|c|c|c|c|c|}
\hline & \multicolumn{4}{|c|}{ December 2003} & \multicolumn{4}{|c|}{ December 2005} & \multicolumn{4}{|c|}{ December 2006} \\
\hline & Number & $\begin{array}{l}\text { Assets } \\
\text { (Rs Mn) }\end{array}$ & $\begin{array}{c}\text { In percent of } \\
\text { total assets }\end{array}$ & $\begin{array}{l}\text { In percent } \\
\text { of GDP }\end{array}$ & Number & $\begin{array}{c}\text { Assets } \\
\text { (Rs Mn) }\end{array}$ & $\begin{array}{c}\text { In percent of } \\
\text { total assets }\end{array}$ & $\begin{array}{l}\text { In percent } \\
\text { of GDP }\end{array}$ & Number & $\begin{array}{c}\text { Assets } \\
\text { (Rs Mn) }\end{array}$ & $\begin{array}{c}\text { In percent of } \\
\text { total assets }\end{array}$ & $\begin{array}{l}\text { In percent } \\
\text { of GDP }\end{array}$ \\
\hline Commercial banks $1 /$ & 22 & 322,854 & 74.5 & 205.1 & 19 & 468,596 & 76.5 & 252.8 & 19 & 630,120 & 95.3 & 306.8 \\
\hline Privately-owned & 19 & 273,035 & 63.0 & 173.5 & 16 & 404,280 & 66.0 & 218.1 & 16 & 562,393 & 85.1 & 273.9 \\
\hline Domestic & 2 & 78,754 & 18.2 & 50.0 & 1 & 94,479 & 15.4 & 51.0 & 1 & 102,672 & 15.5 & 50.0 \\
\hline Foreign & 17 & 194,282 & 44.8 & 123.4 & 15 & 309,801 & 50.6 & 167.1 & 15 & 459,721 & 69.5 & 223.9 \\
\hline State-owned & 3 & 49,819 & 11.5 & 31.7 & 3 & 64,316 & 10.5 & 34.7 & 3 & 67,727 & 10.2 & 33.0 \\
\hline Non-bank deposit-taking institutions $2 /$ & 14 & 26,949 & 6.2 & 17.1 & 15 & 35,420 & 5.8 & 19.1 & 14 & 31,026 & 4.7 & 15.1 \\
\hline Leasing companies & 10 & 8,022 & 1.9 & 5.1 & 11 & 12,033 & 2.0 & 6.5 & 10 & 12,931 & 2.0 & 6.3 \\
\hline Parastatals & 4 & 18,926 & 4.4 & 12.0 & 4 & 23,387 & 3.8 & 12.6 & 4 & 18,095 & 2.7 & 8.8 \\
\hline Development Bank of Mauritius & 1 & 7,013 & 1.6 & 4.5 & 1 & 7,226 & 1.2 & 3.9 & & & & \\
\hline Mauritius Housing Company & 1 & 6,639 & 1.5 & 4.2 & 1 & 6,899 & 1.1 & 3.7 & 1 & 7,026 & 1.1 & 3.4 \\
\hline SICOM Financial Services Ltd & 1 & 1,742 & 0.4 & 1.1 & 1 & 2,290 & 0.4 & 1.2 & 1 & 2,447 & 0.4 & 1.2 \\
\hline Mauritius Civil Service Mutual Aid Association Ltd 3/ & 1 & 3,532 & 0.8 & 2.2 & 1 & 6,972 & 1.1 & 3.8 & 1 & 8,622 & 1.3 & 4.2 \\
\hline Total contractual savings $4 /$ & & 73,582 & 17.0 & 46.8 & $\ldots$ & 95,945 & 15.7 & 51.8 & $\ldots$ & & & \\
\hline Domestic insurance companies & 19 & 32,592 & 7.5 & 20.7 & 19 & 42,139 & 6.9 & 22.7 & $\ldots$ & $\ldots$ & $\ldots$ & $\ldots$ \\
\hline Life insurance & & & & & 4 & 18,264 & 3.0 & 9.9 & & & & \\
\hline Non-life insurance & $\ldots$ & $\ldots$ & $\ldots$ & $\ldots$ & 5 & 1,573 & 0.3 & 0.8 & $\ldots$ & $\ldots$ & $\ldots$ & $\ldots$ \\
\hline Composite & $\ldots$ & $\ldots$ & $\ldots$ & $\ldots$ & 10 & 22,302 & 3.6 & 12.0 & $\ldots$ & $\ldots$ & $\ldots$ & $\ldots$ \\
\hline Occupational pension funds & $\ldots$ & 20,709 & 4.8 & 13.2 & ... & 21,607 & 3.5 & 11.7 & $\ldots$ & $\ldots$ & $\ldots$ & $\ldots$ \\
\hline National pension fund & 1 & 29,507 & 6.8 & 18.7 & 1 & 38,213 & 6.2 & 20.6 & & & & \\
\hline National savings fund & 1 & 4,485 & 1.0 & 2.8 & 1 & 6,398 & 1.0 & 3.5 & $\ldots$ & $\ldots$ & $\ldots$ & $\ldots$ \\
\hline Less insured pension schemes & $\ldots$ & 13,711 & 3.2 & 8.7 & $\ldots$ & 12,413 & 2.0 & 6.7 & $\ldots$ & $\ldots$ & $\ldots$ & $\ldots$ \\
\hline Offshore insurance companies 5/ & 14 & 10,074 & 2.3 & 6.4 & 18 & 12,703 & 2.1 & 6.9 & $\ldots$ & $\cdots$ & $\ldots$ & $\ldots$ \\
\hline FINANCIAL SYSTEM ASSETS & & 433,459 & 100.0 & 275.4 & & 612,664 & 100.0 & 330.5 & & 661,146 & 100.0 & 321.9 \\
\hline \multicolumn{13}{|l|}{ Memorandum items: } \\
\hline Investment management companies & 14 & 2,432 & 0.6 & 1.5 & 16 & 2,852 & 0.5 & 1.5 & $\ldots$ & $\ldots$ & $\ldots$ & $\ldots$ \\
\hline Brokerage houses & 22 & 845 & 0.2 & 0.5 & 26 & 634 & 0.1 & 0.3 & & & & \\
\hline Stockbroking companies & 11 & 545 & 0.1 & 0.3 & 11 & 244 & 0.0 & 0.1 & $\ldots$ & $\ldots$ & $\ldots$ & $\ldots$ \\
\hline Insurance brokers & 11 & 300 & 0.1 & 0.2 & 15 & 390 & 0.1 & 0.2 & $\ldots$ & $\ldots$ & $\ldots$ & $\ldots$ \\
\hline Mutual funds & 5 & 1,085 & 0.3 & 0.7 & 6 & 1,924 & 0.3 & 1.0 & $\ldots$ & & $\ldots$ & \\
\hline Stock Market (Official) Capitalization & & 51,230 & & 32.5 & & 80,038 & & 43.2 & & 116,981 & & 57.0 \\
\hline Stock Market (DEM) Capitalization 6/ & & & & & & 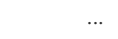 & & & & 44,219 & & 21.5 \\
\hline \multicolumn{13}{|l|}{ Banks' assets by location of activity $7 /$} \\
\hline Total bank assets (domestic market) & 10 & 170,211 & $\ldots$ & 108.1 & $\ldots$ & 189,485 & $\ldots$ & 102.2 & $\ldots$ & 202,483 & $\ldots$ & 98.6 \\
\hline Total bank assets (non-resident business) & 12 & 152,644 & & 97.0 & $\ldots$ & 250,310 & $\ldots$ & 135.0 & $\ldots$ & 406,793 & & 198.1 \\
\hline
\end{tabular}

Sources: Bank of Mauritius (BOM); and the Financial Services Commission (FSC).

1/ From June 2005, there is a single banking license in Mauritius, allowing all banks to provide both offshore and onshore services. Hence 2003 data aggregates former Category 1 (onshore) and Category 2 (offshore) banks.

2/ There are also 300 cooperative credit institutions, credit unions, and cooperative thrift institutions. Their balance sheet data is not available.

$3 /$ This association is a civil service credit union. However, its board is government appointed.

$4 /$ Total contractual savings is the sum of the assets of domestic insurance companies, occupational pension funds, NPF, and NSF, less insured pension schemes.

$5 /$ Assets refer to 12 companies in 2003 and 18 companies in 2005 .

6/ The Development and Enterprise Market (DEM) is a second-tier market created in 2006 to replace the OTC market.

7/ Non-resident market refers to Category 2 banks in 2003 and Segment B activity (generating foreign source income) in 2005 and 2006. Domestic market refers to Category 1 banks in 2003

and to Segment A activity (non-segment B) in 2005 and 2006. 


\section{A. Banking System}

\section{Structure of the banking system}

\section{The banking system is highly concentrated-two long-established domestic and} two international banking groups dominate. There are 19 commercial banks and 14 nonbank deposit-taking institutions. The latter consist mainly of leasing companies but also include parastatal institutions such as the Development Bank of Mauritius, and the Mauritius Housing Company (MHC). Since the introduction of a single license, four types of banks can be distinguished: four large banks serve both the domestic and foreign market, three large foreign banks serve almost exclusively nonresidents, ${ }^{3}$ five small-and medium-banks are still focused on the nonresident market, but pay increased attention to domestic business; and five small- and medium-sized banks largely serve the domestic market (see Table 3). ${ }^{4}$

Table 3. Mauritius: Asset Composition and Performance Measures by Bank Type, 2006

(In percent)

\begin{tabular}{|c|c|c|c|c|}
\hline & \multicolumn{4}{|c|}{ Bank Types } \\
\hline & $\begin{array}{c}\text { Banks in Domestic } \\
\text { and Foreign } \\
\text { Markets }\end{array}$ & $\begin{array}{c}\text { Type } 2 \text { Large } \\
\text { Banks in Foreign } \\
\text { Markets }\end{array}$ & $\begin{array}{l}\text { Type } 3 \text { Smaller } \\
\text { Banks Largely in } \\
\text { Foreign Markets }\end{array}$ & $\begin{array}{c}\text { Type } 4 \text { Smaller } \\
\text { Banks in Domestic } \\
\text { Market }\end{array}$ \\
\hline \multicolumn{5}{|l|}{ Asset Composition } \\
\hline Domestic assets & 43.4 & 1.0 & 23.6 & 90.6 \\
\hline Foreign-sourced assets & 56.6 & 99.0 & 76.4 & 9.4 \\
\hline Total & 100 & 100 & 100 & 100 \\
\hline \multicolumn{5}{|l|}{ Performance Measures } \\
\hline Capital adequacy ratio & 16.2 & 12.7 & 16.8 & 14.0 \\
\hline Return on assets & 1.8 & 1.6 & 1.3 & -0.4 \\
\hline Return on equity & 20.4 & 22.4 & 9.3 & -3.9 \\
\hline Return on assets (less one) $1 /$ & 1.8 & 1.6 & 1.7 & 0.6 \\
\hline Return on equity (less one) $1 /$ & 20.4 & 22.4 & 11.6 & 6.1 \\
\hline Share of branches & 64.9 & 1.7 & 8.0 & 25.3 \\
\hline Share of employees & 77.3 & 1.4 & 6.4 & 14.8 \\
\hline
\end{tabular}

Source: Bank of Mauritius and staff estimates.

$1 /$ The returns on assets and equity have been adjusted to exclude the results of a loss-making bank in each of the Type 3 and 4 groups.

\footnotetext{
${ }^{3}$ Nonresident business is generated by customers of the international business sector.

${ }^{4}$ One South African-owned bank is being wound up following its decision to withdraw from the market.
} 
9. The distinction among bank types is associated with differences in performance and strength. The four largest banks (Type 1) dominate the system, holding 85 percent of domestic and 70 percent of all banking assets. At the other end of the spectrum, Type 4 banks have less than 4 percent of overall assets. Profits reflect the positive effects of market share (Type 1 banks) on results and the costs of being a small market entrant (Types 3 and 4 banks). As Table 3 illustrates, all four types have comfortable capital adequacy ratios although, while all banks meet the required capital, there are substantial differences among banks within each group. Type 3 banks' average capital adequacy exceeds that of the Type 1 banks, with two of the Type 3 banks having capital adequacy more than twice required levels. The Type 3 and 4 banks targeting, or operating in, the domestic market have a somewhat high (relative to assets) share of branches and employees, and hence presumably higher average costs. The weaker financial positions overall of Type 3 and Type 4 banks are also borne out by the stress testing results discussed below.

10. In response to the changed economic outlook, banks have been reducing their exposure to sugar and agriculture, and increasing loans to the personal and tourism sectors (Table 4). While the data prior to December 2005 are not comparable to earlier data, as a result of the licensing change, discussions with the banks indicate that there have been no underlying significant changes. ${ }^{5}$ There is evidence that capital adequacy is improving (the required capital adequacy ratio (CAR) is 10 percent), and there has been a recent decrease in nonperforming loans (NPLs).

\section{Stress tests}

\section{Banks' profitability and comfortable capitalization provide important cushions} against shocks. The stress tests suggest that challenges are concentrated in the medium-and smaller banks whose risk analysis would be least advanced. While the larger banks have begun more rigorous risk assessment, anticipation of events that could adversely affect the smaller banks through, for example, the use of stress tests, would increase the authorities' capacity to address vulnerabilities.

\footnotetext{
${ }^{5}$ Following the licensing change, data for banks serving the offshore market (the former Category 2) are reflected in the FSIs after June 2005. This produces a structural break in the series, resulting, for e.g., in a higher proportion of FX loans from June 2005. This hampers a full view of developments. Sufficiently detailed information was not available, however, to construct a consistent series.
} 
Table 4. Mauritius: Financial Soundness Indicators for the Banking Sector, 2002-2006 1/ 2/ (In percent, unless otherwise indicated)

\begin{tabular}{|c|c|c|c|c|c|c|}
\hline & $\begin{array}{l}\text { Dec. } \\
2002\end{array}$ & $\begin{array}{c}\text { Dec. } \\
2003\end{array}$ & $\begin{array}{c}\text { Dec. } \\
2004\end{array}$ & $\begin{array}{l}\text { Dec. } \\
2005\end{array}$ & $\begin{array}{c}\text { Jun. } \\
2006\end{array}$ & $\begin{array}{l}\text { Dec. } \\
2006\end{array}$ \\
\hline \multicolumn{7}{|l|}{ Capital adequacy } \\
\hline Regulatory capital to risk-weighted assets 3 / & 12.3 & 14.2 & 15.0 & 15.4 & 15.5 & 15.8 \\
\hline Regulatory Tier I capital to risk-weighted assets 4/ & 13.0 & 13.7 & 13.7 & 13.5 & 13.9 & 13.7 \\
\hline Total (regulatory) capital to total assets & 7.2 & 8.0 & 7.8 & 7.8 & 7.8 & 7.3 \\
\hline \multicolumn{7}{|l|}{ Asset composition and quality } \\
\hline \multicolumn{7}{|l|}{ Share of loans (exposures) per risk weight (RW) category } \\
\hline $\mathrm{RW}=0 \%$ & 9.5 & 5.2 & 6.4 & 16.6 & 13.9 & 12.8 \\
\hline $\mathrm{RW}=20 \%$ & 0.4 & 4.8 & 6.7 & 0.2 & 0.8 & 1.3 \\
\hline $\mathrm{RW}=50 \%$ & 7.0 & 7.9 & 9.6 & 6.5 & 6.8 & 6.0 \\
\hline $\mathrm{RW}=100 \%$ & 83.2 & 82.1 & 77.3 & 76.7 & 78.5 & 79.8 \\
\hline Total exposures/total assets & 51.6 & 47.8 & 45.9 & 53.6 & 43.4 & 40.1 \\
\hline \multicolumn{7}{|l|}{ Sectoral distribution of loans to total loans } \\
\hline Agriculture & 9.7 & 9.1 & 7.5 & 5.7 & 5.8 & 5.7 \\
\hline of which: sugar & 8.6 & 8.0 & 6.4 & 5.6 & 5.2 & 5.0 \\
\hline Manufacturing & 16.1 & 14.8 & 13.6 & 12.0 & 11.6 & 11.2 \\
\hline of which: export enterprise certificate holders & 9.4 & 7.5 & 6.1 & 5.4 & 5.3 & 4.8 \\
\hline Traders & 14.1 & 14.9 & 14.5 & 13.9 & 13.8 & 14.9 \\
\hline Personal and professional & 9.2 & 9.8 & 10.0 & 9.4 & 9.1 & 9.5 \\
\hline Construction & 13.9 & 14.2 & 16.2 & 15.2 & 15.2 & 15.4 \\
\hline of which: housing & 10.5 & 9.0 & 10.8 & 10.7 & 11.1 & 12.0 \\
\hline Tourism/hotels 5/ & 15.0 & 15.9 & 15.4 & 13.2 & 12.0 & 13.2 \\
\hline Other & 21.3 & 21.2 & 22.8 & 30.7 & 31.6 & 30.1 \\
\hline FX loans to total loans & 10.3 & 10.9 & 12.2 & 51.5 & 46.1 & 50.7 \\
\hline NPLs to gross loans 6/ & 8.3 & 9.6 & 8.1 & 4.0 & 4.6 & 3.0 \\
\hline NPLs net of provisions to capital & 34.0 & 28.1 & 22.4 & 11.4 & 10.6 & 7.0 \\
\hline Large exposures to capital $7 /$ & 263.7 & 220.9 & 200.0 & 250.3 & 410.2 & 380.0 \\
\hline \multicolumn{7}{|l|}{ Earnings and profitability } \\
\hline ROA(pre-tax net income/average assets) & 2.0 & 2.1 & 2.1 & 1.9 & 1.8 & $\ldots$ \\
\hline ROE(pre-tax net income/average equity) & 18.1 & 19.2 & 19.2 & 21.1 & 20.7 & $\ldots$ \\
\hline Interest margin to gross income & 32.6 & 32.1 & 34.7 & 36.3 & 34.7 & $\ldots$ \\
\hline Noninterest expenses to gross income & 23.1 & 23.9 & 27.7 & 20.1 & 19.6 & $\ldots$ \\
\hline Expenses to revenue ratio & 10.5 & 10.6 & 10.2 & 8.1 & 9.2 & $\ldots$ \\
\hline Average earnings per employee (in Rs'000) & 1,819 & 2,212 & 2,433 & 2,904 & 2,889 & $\ldots$ \\
\hline \multicolumn{7}{|l|}{ Liquidity } \\
\hline Liquid assets to total assets ratio & 32.7 & 36.6 & 37.9 & 44.1 & 48.9 & 52.8 \\
\hline Liquid assets to total short-term liabilities ratio & 65.3 & 71.0 & 71.7 & 88.6 & 106.5 & 118.8 \\
\hline Funding volatility ratio & 16.4 & 13.9 & 14.0 & -20.1 & -38.8 & -51.6 \\
\hline Demand deposits to total liabilities ratio & 10.3 & 10.3 & 10.7 & 15.9 & 13.6 & 15.4 \\
\hline FX deposits to total deposits ratio & 11.7 & 11.0 & 13.8 & 57.3 & 60.5 & 68.0 \\
\hline \multicolumn{7}{|l|}{ Sensitivity to market risk } \\
\hline Net open positions in FX to capital & 7.5 & 20.8 & 1.9 & 4.2 & 3.8 & 6.4 \\
\hline
\end{tabular}

Source: Bank of Mauritius.

1/ The ratios were computed using the standard definition provided in the IMF's Financial Soundness Indicators Manual. The ratios may be different from those used in other parts of the report.

2/ Banking sector refers to former Category 1 banks (domestic market) up to December 2004 and to all banks as from June 2005.

3/ Regulatory capital refers to total Tier 1 and Tier 2 capital less investments in subsidiaries and associates.

4/ Tier 1 capital does not reflect deductions for investments in subsidiaries and associated companies.

5/ The definition encompasses all exposures towards the tourism industry.

6/ Gross loans exclude accrued interest.

7/ Prior to June 2006, data refer to Category 1 (domestic) banks only. 
12. The stress tests comprised sensitivity and scenario analyses. Both took as the baseline the current adverse situation in which there has been a 17 percent deterioration in the terms of trade over the past three years, an increase in treasury bill rates of 5-6 percentage points over the last 6 months/1 year, and a depreciation of 7 percent of the real effective exchange rate in the last two years. The stress test scenario assumed a further change in these three variables of similar magnitude. Sensitivity shocks were also considered that assumed 20 percent losses on the sugar and textile portfolios, and 10 percent on the personal and tourism books. In addition, the effect of shocks to liquidity and large loans was considered (see Box 1).

13. As identified in the previous FSAP, credit risk represents the most significant vulnerability to the banks. Banks have limited direct interest rate and currency risk so both interest rate and currency risk ultimately impact the banks as credit risk. Banks undertake little long-term lending at fixed rates - the practice is to automatically re-price both loans and deposits in relation to each bank's reference rates. Further, investment holdings are principally of maturities of less than one year. Similarly, because of limited foreign currency lending in the domestic market and net currency exposure limits, in general a currency depreciation would have a limited direct impact on the banking system. Indirectly, however, higher interest rates would adversely affect borrower costs and the impact of an exchange rate depreciation could be quite significant. Although certain exports would most likely benefit (sugar, tourism), high import content would result in higher costs, increased inflation, and could eventually result in higher interest rates and lower credit quality.

14. To test the effects of shocks to credit quality, either directly or through price, interest rate, and exchange rate movements, simplifying assumptions were made about the transmission mechanism. In the absence of a model integrating macro and credit risks for Mauritius, the scenario tests estimated how much of an assumed credit loss each bank could absorb from excess capital and profitability over two years while maintaining its regulatory CAR. The sensitivity tests considered how sector-specific provisioning would impact the CAR (see Box 1 for further details).

15. The stress tests indicate that the core of the banking system (the top four banks) would appear to be fairly robust, though one could become undercapitalized in higher stress scenarios. Further mitigating these risks, the larger banks could rely on their strong market position to increase spreads and charges and to boost profitability in all but the worst stress scenarios.

16. The greatest challenges would be faced by the medium and small banks. These institutions are trying to carve out a business without the advantages of scale, franchise, management, and capital which the larger banks enjoy. Moreover, the stress tests indicate that the CAR of four smaller banks, with some four percent of system deposits, would fall below the required 10 percent in several cases. 


\section{Box 1. Stress Tests}

Four sets of tests were carried out:

Scenario: Generalized shock arising from higher interest rates (5 percent), a currency depreciation (20 percent), and a deterioration in the TOT (20 percent) at current profit levels

It was assumed that the combination of these shocks would translate into domestic loan losses, and the test considered the provisioning which could be provided from two years' worth of current profits and the capital currently held in excess of the required minimum. Overall, banks were able to absorb provisions of over 25 (15) percent of the domestic (total) loan book, reducing their profits to zero for two years, while maintaining the required CAR of 10 percent. In one large bank, the CAR fell marginally below 10 percent.

Sensitivity to sector-specific credit shocks to sugar and textiles, tourism, and personal sectors

To test the impact of sectoral credit shocks, the effect of provisioning for losses on credit to the sugar, textiles, tourism, and personal sectors was considered. An immediate write-off of 20, 20, 10, and 10 percent, respectively, of loans to those sectors was assumed, together with an additional 2 percent of the remainder of the loan book to represent indirect effects. The shocks to the textile and sugar sectors were estimated together to represent a worsening of the existing conditions in those sectors. A scenario combining all shocks was also assessed. The CAR of three small banks with 3 percent of deposits fell below 10 percent in all cases. In the most severe shock 1 large bank's CAR fell below 10 percent.

\section{Large exposures}

To take account of the concentration of risk common in small banking systems, the impact on capital adequacy of a 50 percent loss on each bank's third largest credit exposure was assumed. The CAR of the system fell from 15.7 to 13.5 percent; all large banks' CAR remained above 10 percent except in the case of a branch bank where large exposures are supported by group capital. The CAR of 4 smaller banks, representing 6.5 percent of deposits, fell below the required minimum.

\section{Liquidity}

Banks are generally liquid. Potential liquidity events affecting all deposits, short-term deposits and large deposits were evaluated. In all banks, liquid assets would cover: a) over 35 percent of total deposits; b) over 50 percent of demands, savings, and time deposits under 30 days; and c) over approximately 70 percent of all large deposits.

\section{Small banks hold a particularly high share of domestic government securities, although the banking system's holdings have declined relative to total credit. Small banks hold between 20-30 percent of their assets in government securities, with one bank}


holding over 60 percent. The large banks hold between 5 and 12 percent of assets. Banking system holdings have fallen from 19 to 15 percent of advances between 2002 and $2006 .{ }^{6}$ Smaller banks' CAR would fall below the regulatory minimum if required to write down more than 3 percent of the value of these securities. Since most banks typically hold government debt to maturity, this situation is not likely to arise.

\section{B. Other Financial Institutions and Markets}

\section{Contractual Savings}

18. The contractual savings industry is well-developed relative to most developing countries but lags that in some comparable small economies. Assets of insurance companies and pension funds corresponded to 52 percent of GDP in 2005, up from 41 percent in 2001. These intermediaries have in general continued to perform well. Investments in government securities by insurance companies have grown from 8 percent of assets in 2001 to 24 percent in 2005, reflecting the increasing supply of longer-term instruments, and the growth of overseas investments by both insurance companies (which are still constrained by the limit of 25 percent on their foreign assets) and pension funds (which are not subject to the same restriction). Several pension funds have invested between 30 and 50 percent of their assets in overseas securities and have achieved very satisfactory investment returns while also diversifying their risks.

19. Competition in the insurance sector has intensified in recent years, reflecting the fight for market share in the absence of large losses from cyclones. Premiums have fallen and some segments, such as motor insurance, now operate with significantly lower operating ratios. Two small insurance companies have been intervened. These companies are likely to join four other small companies that were forced to exit the market in the past decade. The liquidation of these companies, which were mainly motor insurance, caused large losses to other insurers, while some claims by beneficiaries remain to be settled. ${ }^{7}$

\section{The National Pension Fund (NPF) has assets equivalent to 21 percent of GDP} and is a major participant in the government bond market. The NPF, with total assets of MUR 38 billion in 2005, has continued to perform satisfactorily: return on investment was 6.9 percent of assets in the year to June 2005. Sixty percent of total assets are invested in government securities, 10 percent in foreign assets, and 10 percent in foreign currency deposits. The last two classes benefited from the recent depreciation of the exchange rate.

\footnotetext{
${ }^{6}$ Comparable data are used for advances.

${ }^{7}$ In motor insurance claims paid by one insurance company may be recovered from the insurer of the driver at fault when fault is established.
} 
The NPF participates in the government bond market but it has occasionally been unable to purchase bond at the auctions.

\section{Capital markets}

21. Mauritius, like many markets around the world, has experienced a strong bull market in recent years. In 2005-06, the market ended the year with a 16.3 percent growth over 2004-05 levels, market capitalization grew by 22.9 percent, and total value traded increased by 42.4 percent over the previous year's level. In line with trends in emerging markets, the SEM witnessed a strong increase in net foreign portfolio flows during 2005-06; MUR 1.3 billion (US\$41.9 million) was invested, the highest level recorded since the market was opened to foreign investors in 1994. The Stock Exchange is marginally profitable. In 2006 it created a new second tier, the Development Enterprise Market, which replaces the former OTC market and enhances transparency and disclosure for smaller companies trading on the SEM.

\section{The institutional and technical infrastructure of the SEM is highly developed,} but the market is characterized by low volume and poor liquidity as is typical of small economies. As of year end 2006, there were 41 companies listed on the official list, market capitalization was 57 percent of GDP, (versus 27 percent in 2002), and turnover represented 5 percent of market capitalization. There has been only one IPO in the past several years, and that company has now de-listed. Many of the companies listed on the exchange are controlled by a dominant shareholder, often a family-owned conglomerate. This ownership structure constrains capital raising on the market, as dominant shareholders are reluctant to cede control to external shareholders. Privatizations of large state-owned companies, unbundling of conglomerates, or closer ties to other exchanges (e.g., Johannesburg) could positively impact the development of the stock market.

\section{The international business sector}

23. Mauritius has developed a niche industry in the increasingly competitive global business sector. As of end January 2007, the sector included 30,832 licensed global business companies (GBCs) - of which 463 represented registered Global Funds with a net asset value (NAV) of US\$35.9 billion, and 78 global management companies, in addition to banks which are active in the global business center. The sector appears to be growing rapidly, as evidenced by the significant increase in the assets generating the foreign-sourced income of the banking sector, which grew from 135 percent of GDP in 2005 to 198 percent in 2006.

24. The sector provides important economic benefits but is vulnerable. This accounts for approximately 25 percent of all corporate tax revenue, and the sector was originally spurred by tax considerations; notably a particularly favorable double taxation avoidance 
treaty (DTAT) with India, which accounts for roughly 55 percent of the global business sector (down from 85 percent a few years earlier). ${ }^{8}$ However, the dependence on tax considerations represents a risk for the sector, particularly since these are receiving greater scrutiny abroad (Mauritius is by far the largest source of FDI and portfolio investment in India). Thus, the boon this sector produces for Mauritius is vulnerable to changes in tax treaties and reputational risks, and requires the adoption of international regulatory standards, which has large regulatory costs.

25. Mauritius has had some success in reducing its dependence on the Indian DTAT, both through the use of its extensive network of DTATs with other countries, and by diversifying into other areas of global business. The relative shortage of highly skilled legal and financial expertise in Mauritius, however, represents a potential bottleneck to rapid growth of higher-value-added global financial services. The 2006/07 budget speech provided for improved entry for international law firms and foreign professionals. The local legal community appears to be resisting law firm entry, however. It will be important to clarify the legal status of international law firms rapidly, as they can bring much needed skills, expertise, and business to Mauritius' global business sector.

\section{Financial Sector Supervision ANd Regulation}

\section{A. Regulatory Reforms and Developments}

\section{Banking}

26. The BOM has worked to accomplish the improvements recommended in the 2002 FSAP, and there has been significant progress on both primary and secondary legislation. In October 2004, the Bank of Mauritius Act 2004 (BOMA) and the BA were enacted, replacing statutes dating from 1981 and 1988, respectively. Both acts now clearly define the supervisory objectives of maintaining soundness and stability in the financial sector. The BOMA establishes a fixed term appointment for the governor of the central bank, provides protection for the BOM's staff against legal action for actions taken in good faith for the performance of their official duties, and states that "...the bank shall, in the pursuit of its objects, perform its functions independently." The BA removes ministerial powers to direct the supervisory authority and the possibility of appeal to the prime minister on licensing and ownership decisions. The BA also provides the regulator additional powers to curb bank actions and management when warranted by soundness considerations. Significant resources have also gone into the development of guidance notes and guidelines for the industry.

\footnotetext{
${ }^{8}$ Under the DTAT residents of Mauritius are not taxed on capital gains arising from the sale of securities in India, and Mauritius has no capital gains tax. Companies therefore register in Mauritius to invest in India.
} 
27. Challenges center on operational issues and supervisory practices. Supervisory resources could become more effective through adoption of a more risk-focused approach to onsite examinations. Examination processes focus on compliance with rules rather than being comprehensively based on the risks in the banking system. Methods of retrieving, processing, and storing of data related to off-site reporting are cumbersome, as noted in the 2002 FSAP. Procedures for intervention in the case of a distressed institution are unwieldy and risk regulatory forbearance by providing opportunities for delay. Work should continue on implementation of previous advice on bank supervision and its legal framework.

28. The Basel Core Principles assessment, based on the 2006 revision, found that while BOM has made progress in regulation, considerable work remains. Licensing, risk evaluation, cross-border supervision and corrective powers were among the areas that needed strengthening. Given the weak balance sheets of some of the smaller banks, inadequate supervisory capability in risk evaluation could limit early intervention. Nonetheless, confidence in large Mauritian banks has proved very resilient in the face of adverse events, and it is likely that the eventual failure of a small bank would not have a significant effect on confidence in the banking system as a whole.

29. Nonbank legislation, particularly related to anti-money laundering and countering the financing of terrorism (AML/CFT), has impacted the responsibilities and work practices of the BOM. The Financial Intelligence and Anti-Money Laundering Act 2002 (FIAML) provided for the establishment and management of a financial intelligence unit (FIU) as the central agency responsible for requesting, receiving, analyzing and disseminating to the BOM (among other authorities), disclosures of financial information concerning suspected proceeds of crime and alleged money-laundering offences. Under the FIAML regulations, financial institutions are required to implement internal controls and other procedures for AML/CFT that, among other things, includes establishing and maintaining a manual of compliance procedures in relation to money laundering and programs for assessing risks relating to ML and FT. The BOM has assumed a key role, as supervisor, in seeing that the prescriptions of the FIAML and its regulations are observed.

\section{Contractual savings}

\section{Considerable progress has been made in the ambitious program of} modernization of insurance regulation and supervision, but much is still at the planning stage. On the positive front, a new IA that creates a modern legal and regulatory framework was enacted in 2005. Proclamation of the act has been delayed by the need to ensure effective consultation of the insurance industry on the implementing regulations, especially the introduction of risk-based solvency rules. The drafts of several new regulations, including revised solvency rules, are nearing completion and proclamation of the act is likely in the next parliamentary session. Other positive developments include the completion of on-site inspections of 11 companies and the appointment of inspectors in two small companies that face financial difficulties. Direct insurance overseas by residents will be allowed after a transition period of five years. 
31. Insurance regulation and supervision continue to suffer from several important shortcomings. There is a shortage of qualified and experienced staff, little progress has been made in developing and implementing an early warning system, and supervision (both offsite surveillance and on-site inspections) continues to be focused on rule compliance rather than on assessing the effectiveness of internal controls and risk management. Quarterly statistical returns started to be collected in early 2005 but the data are not used to identify companies facing financial difficulties or breaching standards of prudent behavior. The establishment of an insurance information network remains a medium-term challenge. The proposed new solvency rules will clarify the calculation of insurer insolvency, and strengthen the intervention powers of the FSC.

32. Pension fund regulation continues to be fragmented among several laws and tax regulations. A draft bill has been prepared but considerable consultation with the insurance and pension sector is still required for its finalization. The draft bill provides for necessary modernization in several areas, including licensing, appointment of pension scheme managers, administrators and investment managers, fund governance, appropriate funding levels and actuarial evaluations, vesting and portability rights, asset segregation and safe custody, and asset valuation and diversification. Enactment of the bill should be expedited.

\section{An independent investment committee with full executive powers is to be} established for the NPF. The authorities should take action to set up the committee whose decisions will help to improve the asset management function of the NPF.

\section{Capital markets}

34. Since the 2002 FSAP, there have been several developments in capital market regulation. A new, comprehensive SA has been enacted but not yet proclaimed into force. The Act and proposed regulations address the legal and regulatory gaps noted in the 2002 FSAP. It requires an extensive amount of implementing regulation being put into place. Given the development of the collective investment scheme market and possible issues of market abuse, effectiveness of this legislation should be expedited. The SEM became the second exchange in sub-Saharan Africa (after Johannesburg) to become a member of the World Federation of Exchanges in 2005. The FSC has increased staff and training, and now conducts regular on-and-off site surveillance of market intermediaries.

35. The SA also envisages the allocation of self-regulatory powers to the SEM under a "shared responsibility" model, but the extent of this allocation is as yet uncertain. The FSC has ultimate oversight of the regulatory function of the SEM but under the statute, delegates many regulatory functions to the SEM. Going forward, it is important that the existing close cooperative relationship between the FSC and the SEM be maintained.

Overlapping powers demand coordination and cooperation; gaps or ambiguities in regulatory authority must be avoided. In addition, there is a potential conflict between SEM's shareholders' demands and the exercise of the public interest function and regulatory roles of the exchange. The SEM must ensure that the structural mechanisms are in place and adapted to deal with this potential issue. 


\section{Governance}

36. The effectiveness of key regulatory agencies would be enhanced by improvements in their governance and management. Effective leadership at a time of structural change will improve the authorities' ability to detect and respond to stability and developmental concerns. Key posts should be filled expeditiously.

37. The BOM should, as soon as possible, undertake a thorough professional review of its management, organization, and staffing. Several BOM departments below the deputy governor level lack heads. Several vacancies also exist among less senior staff. While unfilled posts in part reflect a shortage of qualified staff and competition from the private sector, administrative procedures to fill posts appear cumbersome. Senior management's consent seems required for all recruitment and it appears to have given staffing low priority. In addition, more attention should be paid to staff training and development.

38. At the Financial Services Commission (FSC), senior management and most of the Board were replaced following the last general election. Such a wholesale turnover in senior management and the Board could raise concerns about the independence of the regulator, and was undoubtedly disruptive to the ongoing operations of an important but young institution. In addition, two of the three director positions remain vacant. Both regulatory independence and the perception of independence are important for effective supervision. The authorities should consider granting greater statutory independence to the FSC, and follow sound governance practices by, inter-alia, staggering the appointment and terms of office of members of the Board.

39. There are a number of other key financial sector positions which remain vacant.

They include the CEO and staff at the relatively recently created Financial Reporting Council, which has legal responsibilities under the Financial Reporting Act 2004 (FRA), director of the Debt Management Unit at the Ministry of Finance and Economic Development (MOFED), and Ombudsperson for Banks (Section 96a of the BA). A number of key committees have been established on paper, but not in fact, including the NPF's Investment Committee. This state of affairs has weakened oversight of the financial system.

40. The allocation of regulatory authority for securities market activities among the BOM, the FSC, and the SEM is still unclear. A 2002 MOU between the BOM and the FSC with respect to securities market activities of banks has so far produced little by way of cooperative efforts between the two regulators. This is an area of concern to the extent that there is a potential for regulatory arbitrage and inefficient use of scarce regulatory resources.

\section{DeVElopmental IsSues}

\section{A. Infrastructural Developments}

41. Since 2003, several reforms have been initiated to improve financial market infrastructure. Accounting and auditing, corporate governance, and creditor rights were the 
main areas addressed. The accounting and auditing reform provides professionals with regulatory and technical decision powers over financial reporting, enshrining the framework in the 2004 FRA. The FRA establishes the Mauritius Institute of Professional Accountants (MIPA) as a self-regulatory body with disciplinary powers, and requires that practicing professional accountants join MIPA, obtain a practicing certificate, and register as public accountants. The Act also created a Financial Reporting Council (FRC) to enforce compliance with accounting and auditing standards and as an independent audit regulator.

42. The Code of Corporate Governance launched in $\mathbf{2 0 0 3}$ has improved private sector governance, particularly in listed companies. The code is based on the OECD principles adapted for Mauritian circumstances. Compliance is voluntary, but the code requires that designated companies (comprising listed, large public and private companies, financial institutions, and state-owned enterprises (SOEs)) explain reasons for noncompliance. While there is market consensus that governance has improved in private companies, the governance of SOEs still requires upgrading.

43. The insolvency and creditor rights system is in the early phases of a reform to provide a legal framework and procedures for corporate insolvency and rehabilitation. A draft law addresses a 2004 Insolvency ROSC finding that current legislation is biased towards liquidation. The draft law includes provisions for a comprehensive rehabilitation and a stay of proceedings during rehabilitation, but may not provide sufficiently broad oversight of insolvency practitioners, and requires better integration with Mauritius's civil code.

\section{B. Access to Financial Services}

44. Mauritian households have almost universal access to savings accounts and reasonable access to basic personal credit, but term and higher-risk financing require development. The decrease in private sector credit in 2003-04 and the need for output restructuring in the face of the deteriorated terms of trade have raised concerns about access to finance by small and medium enterprises (SMEs). Improved debtor information, market intermediary involvement in government lending to SMEs, and work to lower intermediation costs are seen as a means of improving access.

45. The Credit Information Bureau, inaugurated in late 2005 at the BOM, is operating satisfactorily but expansion of its coverage could improve access by creditworthy SMEs. All banks in the BOM's clearing and settlement system provide information to the Bureau on loans above MUR 100,000 for individuals and MUR 500,000 for others. Its use is mandatory for all granting of credit. Extending, as intended, its use to other financial intermediaries as well as to nonlicensed credit providers, and lowering the reporting threshold, would improve the quality of information available about small borrowers.

46. Mauritian enterprises perceive the cost of credit as a barrier, but international comparisons do not suggest that bank spreads are excessive. The cost of credit is influenced by wholesale rates, bank spreads, and taxes. An implicit tax is the unremunerated 
reserve requirement of 4 percent of deposits. Consideration could be given to lowering intermediation costs by remunerating reserve requirements. The impact on bank behavior of having different tax rates in effect on domestic- and foreign-sourced income should be kept under review.

47. The government has begun a new program to provide concessional finance to SMEs. Four credit and quasi-equity schemes, differentiated by the amount of financing provided and by administrator, offer loans or redeemable preference shares for 5-year terms at back-loaded rates of interest ranging from 9 percent in year 1 to 13 percent in year 5 . The current program attempts to avoid the high default rates of previous programs through professional project selection. Market intermediaries are being asked to participate in the higher value schemes. Encouraging bank participation in project selection, monitoring and risk-sharing when experience with the scheme has developed may allow banks to become familiar with this high-risk market segment.

\section{Public Debt Management}

48. Mauritius's public sector debt is approximately 70 percent of GDP (in 2005/06), and over half matures within one year, posing significant interest rate and budgetary risks. Exchange rate risk is minimal since only one tenth of the debt is foreign. Mitigation of this risk will depend on both fiscal consolidation and enhanced debt management, including implementation of a maturity-lengthening strategy.

49. A Debt Management Unit (DMU) was established in MOFED in 2002 as part of a decision to reform public debt management. In parallel, an Advisory Committee with sector-wide participation was established to support reforms and debt market development. The planned areas of focus include the legal framework, development of a debt management strategy, and capacity building.

50. A number of measures would support and strengthen reform:

- To provide leadership, it is recommended that a director of the DMU be appointed, and that appropriate staffing of the unit be ensured.

- $\quad$ BOM tasks related to auctions and the back office function for public debt should be performed with clear instructions from the DMU, and regulated in an Agency Agreement between the MOFED and the BOM, which specifies the BOM's roles.

- $\quad$ The DMU has had a consultant advisor who is working on a debt management strategy - there needs to be a strong focus on building capacity of existing staff working with the advisor.

- A medium-term strategy for debt management is under preparation. It is important that the final document focus on risk exposure management, and be finalized, and published no later than mid-2007, under the signature of the Minister of Finance and 
Economic Development. The strategy should be revisited at least annually, e.g., as part of the budget process, and should include an evaluation of new instruments.

- $\quad$ More accurate daily cash forecasting and cash management practices, which are the responsibility of the accountant general's office, are essential for planning the government's borrowing, as well as for monetary policy.

\section{Development of the market for government securities}

51. The domestic debt market is not very well-developed and can impede riskreducing borrowing strategies in public debt management. Treasury bills are held by banks, and long-term securities (with maturities over one year) are mainly held by pension and insurance companies. Secondary market trading is very limited.

52. The government's debt management strategy and borrowing plans should take account of debt market development issues. While market development is not a policy choice, the authorities can facilitate secondary market development, including through their borrowing strategy and issuance method. Relevant measures include:

- Concentration of borrowing in fewer securities to target larger outstanding amounts in individual issues, thus encouraging secondary market trading; and

- A borrowing calendar with a time horizon of up to a quarter could be prepared and published, and the recently introduced practice of announcing issue ranges for the forthcoming auction should be continued, and the ranges gradually narrowed to help the market participants' own planning.

\section{Monetary Policy Operational Framework}

53. The operational framework used to implement the BOM's monetary policy was revised in December 2006 to adopt a repo rate on transactions between the BOM and banks as operational instrument and signal. Since about 1999, the BOM has pursued a monetary policy aimed at using an interest rate instrument to control inflation, though account was also taken of the exchange rate.

54. The legislative and regulatory basis for the new framework was provided in the BOMA, and by the agreements already in place with the banks. The BOMA provided for the independence of the bank and for price stability as one of two primary objectives, and created a Monetary Policy Committee (MPC) of eight persons (including the BOM governors and five others to be appointed by the minister). ${ }^{9}$ The MPC is to be responsible for

\footnotetext{
${ }^{9}$ The other was to promote "orderly and balanced economic development."
} 
formulating and advising the Board on the monetary policy to be pursued. The BOMA also provides for dissemination of monetary policy decisions. Repo operations are governed by the Master Repurchase Agreement revised in January 2007, and by the Primary Dealers' agreement developed in 2002 and revised in 2003.

55. The repo rate for BOM credit was set at 8.5 percent in a corridor of $\pm \mathbf{5 0}$ basis points. Repos are conducted at the fixed upper bound of the corridor, and conversely for reverse repos, with the target rate being the average overnight rate in the interbank money market, where, however, only overnight, uncollateralized credits are used. A standing facility is made available to banks at four percent over the repo rate and at their request.

56. The operational mechanics of the monetary policy framework are in place but key features are still in question. With publication of the target rate of inflation, communication with the banking community, and repo/reverse repo transactions, implementation of the new system has started. However, there have been delays in appointing the advisory MPC. In addition, the analytical framework that defines the BOM's view on the relationship of the repo rate to the rate of inflation that takes account of the specifics of the Mauritian economy and market is still lacking.

57. There also needs to be increased transparency regarding the role and intent of the BOM. A large differential between the treasury bill rate on the primary market and other money market rates began to develop in September 2006. The high treasury bill rate appears to reflect the auction process in a very shallow market at the time of a large public sector borrowing requirement. Some banks have, however, interpreted the treasury bill rate as the rate aimed at defending the rupee by the BOM. Although there is no evidence that this is the case, the large differential places the credibility of the signaling rate in question. ${ }^{10}$

${ }^{10}$ Most recently, the high treasury bill rates have attracted investors and the yields are leveling off. 


\section{APPENDIX I. STATUS OF IMPLEMENTATION OF KEY RECOMMENDATIONS OF THE 2002-03 FSAP}

\begin{tabular}{|c|c|}
\hline Main Recommendations & Progress \\
\hline \multicolumn{2}{|l|}{ Banking and NBFIs } \\
\hline $\begin{array}{l}\text { - Strengthen banking supervision, and } \\
\text { enforce limits on large exposures } \\
\text { and related party transactions. } \\
\text { Ensure adequate level of } \\
\text { provisioning and conservative } \\
\text { valuation of collateral. Encourage } \\
\text { banks and NBFIs to upgrade their } \\
\text { internal audit and control systems. }\end{array}$ & $\begin{array}{l}\text { The legal basis for banking supervision has been strengthened, but concerns } \\
\text { remain about staff resources and their use. A May } 2006 \text { revision of the } \\
\text { "Guideline on Credit Concentration Limits" has been prepared and the BA } \\
\text { also covers large exposures. Quarterly prudential reporting on related party } \\
\text { exposures is not submitted. Under Section } 40 \text { of the } 2004 \text { BA banks have to } \\
\text { establish an Audit Committee consisting of not less than three independent } \\
\text { directors as members. Section } 54 \text { requires every bank to maintain internal } \\
\text { control systems commensurate with the nature and scale of its activities. }\end{array}$ \\
\hline $\begin{array}{l}\text { - Strengthen independence of the } \\
\text { BOM through clearer mandate, full } \\
\text { licensing and regulatory powers, } \\
\text { longer apolitical appointments of } \\
\text { key staff. Subject deposit-taking } \\
\text { nonbanks (leasing companies, the } \\
\text { Development Bank of Mauritius } \\
\text { (DBM), the MHC) to BOM } \\
\text { regulation and supervision and } \\
\text { review the GOM's long-term } \\
\text { strategy concerning public sector } \\
\text { depository institutions. }\end{array}$ & $\begin{array}{l}\text { The BOMA provides the BOM with more powers and independence. In } \\
\text { particular, it provides explicit objectives, contains conditions regarding tenure } \\
\text { of key staff, and specifies that the Board is not subject to direction from any } \\
\text { outsiders. MHC is now supervised by the BOM but the section of the BA } \\
\text { authorizing supervision of the DBM has not been promulgated. A strategic } \\
\text { review of long-term public sector deposit-taking institutions is still required. }\end{array}$ \\
\hline $\begin{array}{l}\text { Introduce a comprehensive credit } \\
\text { information bureau and adopt } \\
\text { appropriate regulation and } \\
\text { nondiscriminatory taxation to foster } \\
\text { the development of nondeposit } \\
\text { taking firms in leasing, factoring } \\
\text { and venture capital. }\end{array}$ & $\begin{array}{l}\text { The BOM established the "Mauritius Credit Information Bureau" in } \\
\text { December 2005. It is currently limited to banks, and has certain minimum } \\
\text { reporting thresholds. } \\
\text { New tax measures have been enacted which have equalized tax treatment } \\
\text { among various types of interest income. }\end{array}$ \\
\hline \multicolumn{2}{|l|}{ Financial sector regulation } \\
\hline $\begin{array}{l}\text { Pass amended BOMA, BA, IA, SA, } \\
\text { Insolvency Act, and prepare } \\
\text { comprehensive new pension fund } \\
\text { regulation. }\end{array}$ & $\begin{array}{l}\text { The BOMA and BA have been in place since 2004, though key sections of } \\
\text { the BA have not yet been proclaimed. The SI and SA were passed in } 2005 \text {, } \\
\text { but have not yet been proclaimed pending finalization of the corresponding } \\
\text { regulations. Insolvency and pension legislation are pending. }\end{array}$ \\
\hline
\end{tabular}




\begin{tabular}{|c|c|}
\hline Main Recommendations & Progress \\
\hline $\begin{array}{l}\text { - Upgrade FSC staffing through } \\
\text { recruitment and training, and } \\
\text { undertake comprehensive program } \\
\text { of on and off-site supervision for all } \\
\text { licensed entities. }\end{array}$ & $\begin{array}{l}\text { A comprehensive recruitment and training program was implemented by } \\
\text { FSC, and it has undertaken a program of regular on and off-site supervision. } \\
\text { However, important vacancies remain. }\end{array}$ \\
\hline $\begin{array}{l}\text { Improve exchange of information } \\
\text { among domestic and foreign } \\
\text { supervisory bodies. }\end{array}$ & $\begin{array}{l}\text { The BOM and FSC's MOU has not been implemented. The two agencies } \\
\text { continue to play an active role in relevant regional and international bodies, } \\
\text { and have signed a number of MOUs with foreign supervisory bodies on } \\
\text { exchange of information. Information exchange has improved but further } \\
\text { progress is required. }\end{array}$ \\
\hline \multicolumn{2}{|l|}{ Public debt management } \\
\hline $\begin{array}{l}\text { Improve public debt management, } \\
\text { distinguish monetary policy } \\
\text { operations issuance from fiscal } \\
\text { financing operations, increase public } \\
\text { debt maturity to reduce roll-over } \\
\text { risk. }\end{array}$ & $\begin{array}{l}\text { The government has gradually been increasing the maturity profile of public } \\
\text { debt, but has not completed development of a public debt management } \\
\text { strategy. The government is in the process of developing a debt management } \\
\text { strategy with assistance from a U.S. Treasury advisor. }\end{array}$ \\
\hline
\end{tabular}




\section{APPENDiX II. Summary AsSessment of Compliance With the Basel Core PRINCIPLES FOR EFFECTIVE BANKING SUPERVISION}

\section{General}

58. This assessment of the current state of implementation of the Basel Core Principles (BCPs) has been completed as part of an FSAP Update undertaken jointly by the World Bank and the International Monetary Fund. The assessment was conducted in February 2007 to update the 2002 assessment and reflects banking supervision practices in place as of end-January $2007 .{ }^{11}$

\section{Information and methodology used for assessment}

59. The assessment is based on: (i) the BOM's self-assessment completed in February 2007, together with detailed interviews with BOM staff (ii) reading of laws, regulations, and other documentation on the supervisory framework and on the structure and development of the financial sector; and (iii) meetings with the banking association as well as with individual institutions of different types.

60. The assessment was performed in accordance with the Basel Core Principles Methodology and assessed compliance with only the "essential" criteria therein, as agreed with the authorities. ${ }^{12}$ The assessors had full cooperation from the authorities and received, in principle, the information necessary for the assessment.

\section{Institutional and macro-prudential setting, market structure—overview}

\section{The financial sector comprises commercial banks, parastatal banks,} insurance companies, securities firms, investment funds, pension funds, and leasing companies. Commercial banks dominate, with about 75 percent of the sector's assets, followed by insurance companies (approximately 9 percent) and other deposit takers such as leasing companies (approximately 6 percent).

62. There are 19 commercial banks and 14 nonbank deposit-taking institutions (NBDTIs). The latter consist mainly of leasing companies but also include parastatal organizations, such as the Development Bank of Mauritius, and the Mauritius Housing Company. The banking system is highly concentrated with two long-established domestic and two international banking groups dominant. Four types of banks can be distinguished: the four dominant players are all Type 1, catering to both resident and nonresident clientele; Type 2 banks are virtually totally focused on the nonresident

\footnotetext{
11 The assessment was conducted by Keith Bell, Consultant, and Christo Wiese, Consultant.

${ }^{12}$ Issued by the Basel Committee, October 2006.
} 
market; Type 3 banks have about three quarters of their assets in the nonresident market while Type 4 banks are small operators in the domestic market.

63. The banks' funding also reflect their market focus. Three-quarters of Type 1 banks' funds are provided by deposits, slightly under half of which are from residents. Type 2 and 3 banks' funds are sourced 90 and 60 percent, respectively, from deposits of nonresidents and banks abroad.

64. From 2001, the Financial Services Commission (FSC) has been responsible for regulation and supervision of nonbank financial services. These include insurance, securities, asset management, pension funds, collective investment schemes, investment advisory services, leasing, global business and other previously nonregulated nonbank financial activities.

65. The financial condition of the banking system remains generally sound. The market is competitive and some lenders are assuming higher credit risk in pursuit of market share. The BOM's response has been to provide general guidance (by issue of "Guidance Notes") for risk management practices of banks, and to interact regularly with senior management. As of June 30, 2006, the aggregate NPL/gross loans ratio was 4.6 percent; the ratio of NPLs net of provisions to capital was 10.6 percent; the banking system ROA was 1.8 percent; the banking system ROE was 20.7 percent; and the liquidity ratio was 48.9 percent.

\section{Preconditions for effective banking supervision}

66. Macroeconomic policies are generally sound. Growth has averaged almost 4 percent over the last five years, and there is a restructuring strategy in place to address the adverse effects of the terms of trade deterioration. While the banking system is concentrated, the presence of several smaller banks, major banking groups, and ease of entry and exit provide adequate market discipline.

67. Overall, the general legal, business and accounting framework within which the banks operate and banking supervision takes place, is developing well.

\section{Main findings}

68. The Bank of Mauritius Act (BOMA) establishes the BOM as the bank supervisory, regulatory and licensing authority. The BOM is also responsible for supervision, regulation, and licensing of money-changers and foreign exchange dealers and for the deposit-taking activities of nonbank financial institutions. The supervisor has a comprehensive understanding of the market and the roles of the supervised deposittaking institutions in it.

69. The BOM has made progress toward establishing its bank supervision system at the minimum standard which the BCPs represent. However, challenges

remain. (Single issues in the Mauritian environment affect multiple core principles (CPs), 
thereby lowering the overall level of compliance. For example, the failure to implement an MOU between the BOM and the FSC adversely impacts the assessment of 2 CPs.)

70. The BCPs may be grouped into seven major categories: (i) objectives, independence, transparency, powers and cooperation; (ii) licensing and structure; (iii) prudential regulations and requirements; (iv) methods of ongoing supervision;

(v) accounting and disclosure; (vi) corrective and remedial powers of supervisors; and

(vii) consolidated and cross-border banking supervision.

\section{Objectives, independence, powers, transparency, and cooperation, CP 1}

71. Substantial progress has been made in recent years in updating laws and infrastructure relating both directly and indirectly to the BOM and banking. Effective October 12, 2004, a new BOMA and a new Banking Act (BA) received assent, replacing statutes dating from 1981 and 1988, respectively. Sections of the BA remain to be proclaimed. Related legislation and a corporate governance code have also been passed. In December 2005, the Mauritius Credit Information Bureau (MCIB) became fully operational - all participating banks must make the necessary enquiry of the MCIB before extending credit.

72. The BOM has extensive authority to license, supervise and inspect all banks and NBDTIs and an array of powers to control the risks assumed by them. It also has the power to establish prudential safety and soundness standards and regulations, and does so primarily by issue of Guidelines/Guidance Notes. While these have the force of law, they should be drafted in a more legally rigorous style to enhance their enforceability. The BOM's independence as supervisor is, in theory, good. However, recent events involving license "approvals in principle" indicate weakening of supervisory vigilance. Use of supervisory resources in on-and-off-site supervision and its overall management should be more efficient and effective.

\section{The legal infrastructure enables the BOM's cooperation with other} regulators. Several MOUs or information sharing agreements are in place. The BOM and the FSC do not yet hold formal, regularly scheduled meetings and one major "failure to consult" has occurred simultaneously with both the FSC and a fellow regulator overseas.

\section{Appropriate legal protection for bank supervisors is now in place.}

\section{Licensing and structure, CPs 2-5}

75. The BA defines permissible activities and the terms "bank" and "banking business" and also limits use of the term "bank" and its derivatives. The BOM has specific legal authority to approve proposed acquisition of a "significant interest" in an established bank, and can determine the source of the acquirer's funds and apply a "fitand-proper" test; similar criteria apply to bank establishment. There is no reporting procedure for the BOM to keep current with any subsequent changes in beneficial ownership. Incorporation or acquisition of a subsidiary (only permitted in a business 
related to banking) must receive prior approval. Acquisition of holdings of direct proprietary interests is severely circumscribed. There is no quantum restriction where a bank sets up or participates in an "equity fund" approved by the FSC, and no requirement for prior reporting thereof to the BOM.

\section{Prudential regulations and requirements, CPs 6-18}

76. Market risk-related computations, capital charges, and reporting requirements are not in force in Mauritius. Risk-weighted capital adequacy requirements include, from February 2005, a capital charge for operational risk using at least the "Basic Indicator Approach" (applied on a "consolidated" basis in the cases of the two, systemically important, domestic banks). All banks are reported to be above the BOM's "10 percent of risk assets" minimum requirement (CP 6).

77. The BOM has issued Guidance Notes/Guidelines that set more detailed prudential standards for, inter alia, capital adequacy, credit concentration limits, credit impairment and income recognition and classification of assets.

78. The BOM's Guideline on Corporate Governance stipulates general requirements for risk management processes and procedures but does not deal with the management of specific risks in greater detail (CPs 7 -16). Due to the nature and maturity of the banking market, credit risk - although still relatively modest-is the predominant risk. Market risk and interest rate risk are relatively low, as are country and transfer risk. As yet, domestic banks' foreign operations remain limited in scope but are growing.

79. The management of liquidity risk is addressed in a BOM guideline, which again stipulates general requirements for half-yearly reporting. While regulatory reporting is insufficient, liquidity is not an issue since there is surplus liquidity in the market and the foreign-owned institutions have access to funding from their headquarters or parents. There are no specific requirements for the management of interest rate risk in the banking book, and its proper management is not verified by the BOM.

80. The BOM's Guidance Note on General Principles for Maintenance of Accounting and Other Records and Internal Control Systems requires that senior management take account of all significant internal operations to create an effective, comprehensive internal control system (CP 17).

81. Mauritius has implemented the relevant anti-money laundering legislation. The Financial Intelligence and Anti-Money Laundering Act (2002) and Regulations (2003) and the Anti-Money Laundering (Miscellaneous Provisions) Act (2003) are in force. The Financial Intelligence Unit (FIU) is a member of the Egmont Group. Financial professions, among others, are required to report suspicious transactions to the FIU. Account opening procedures require formal identification of the account holder. Banks are obliged to refuse execution of transactions from clients on an anonymous basis. Apart from certain prescribed "exempt transactions," transactions in cash in excess of MUR 350,000 are prohibited altogether. 


\section{Methods of ongoing supervision, CPs 19-21}

82. The BOM is required to perform off-site and on-site inspections. On-site inspections must be performed no less than once every two years and are planned as a function of the findings of the immediately previous examination, the off-site analysis of regulatory reporting and extended reports from external auditors, and carried out pursuant to the BOM's Examination Framework (i.e., guides for use on-site). The Framework lacks modules on, inter alia, liquidity, related party transactions or off-balance sheet exposures, and should be revised to provide comprehensive, standardized procedures. BOM is developing a better understanding of the risk profiles of the supervised institutions but cannot as yet shift its focus from comprehensive to more targeted inspections. A CAMEL system for rating the overall condition of a bank is in use, with results reported to each bank quarterly (CP 19, 20).

83. Meetings with bank managements are held on an "as required" basis throughout the supervisory cycle and meetings are always held with top management at the conclusion of an on-site inspection. The BOM has full authority to request any information needed for supervision. Each year there is a trilateral meeting among the external auditors, the bank's senior management, and senior representatives of the BOM's Supervision Department (SD) (CP 20). (All banks' chief executive officers meet quarterly with the governor; banks' compliance officers meet with senior officials of the SD on a similar schedule.)

84. Prudential reports are submitted both by electronic (online) and hard copy means, reviewed for accuracy and then used as inputs by the portfolio manager for off-site supervisory analysis and any required follow-up (CP 21). More frequent (e.g., loans written off, nonperforming loans and the related provisions are only reported yearly) and more (on liquidity by time buckets, interest rate risk and market risk) reporting would improve off-site supervision,. The method of processing, storing and retrieving data related to off-site reporting is cumbersome. Information provided from bank records is verified periodically through on-site inspections. The banks are required to commission annually from their external auditors extended format reports on their systems of internal control and this is a significant source of supervisory information. Licensees are required to produce audited financial statements, and the BOM has power to reject the (annual) appointment of a bank's external auditor (CP 22).

\section{Accounting and disclosure, CP 22}

85. Banks are required to prepare financial statements and various reports in accordance with International Accounting Standards, as mandated by the Companies Act 2001.

\section{Corrective and remedial powers of supervisors, CP 23}

86. Article 45 of the BA provides the BOM a comprehensive array of remedial powers. However, examination reports of findings and concerns are frequently delivered after a significant delay, thereby delaying implementation of necessary measures. The 
BOM's Guide to Intervention is insufficiently oriented towards securing the orderly exit of weak, ill-managed institutions. The BOM has the power to disqualify Board members and members of senior management for cause (and has, on occasion, done so). The BOM can seek monetary penalties on either banks or members of their managements (as well as custodial sentences for the latter) for willful infringement of applicable legislation and guidelines/guidance notes. Any prosecution would have to be approved by the Director of Public Prosecutions (see also CP 1(4)).

\section{Consolidated and cross-border banking supervision, CPs 24-25}

87. The BOM has legal powers and resources to exercise supervision on a consolidated and sub-consolidated basis. Consolidated supervision, however, is not yet of major importance, due to the limited complexity of Mauritian groups (CP 24).

88. Cross-border cooperation and exchange of information with other relevant supervisors are significant for the BOM as host supervisor of a banking sector with major representation of foreign banks' branches or subsidiaries (FBB/S) (CP 25). The BA provides the necessary legal framework to cooperate with foreign supervisors, exchange information and share supervisory tasks. The BOM has the necessary supervisory tools and is seeking to develop the expertise to discharge competently its task as the domestic institutions' supervisor. Its capacity to support efficiently the consolidated "home" supervisor to perform its tasks is in doubt. Due to the limited impact the $\mathrm{FBB} / \mathrm{S}$ have on the risk profile of the groups of which they are part, BOM should risk-focus its supervision of international groups. The BOM is authorized to supervise the overseas activities of locally incorporated banks and on-site examinations of such activities are taking place. The FBB/S are, in principle, subject to the same prudential examination and reporting requirements as domestic banks (save for corporate governance requirements and "large exposure" lending capacity, where greater quantum provisions exist for them).

Table 5. Recommended Action Plan to Improve Compliance with the Basel Core Principles

\begin{tabular}{|l|l|}
\hline \multicolumn{1}{|c|}{ Reference Principle } & \multicolumn{1}{c|}{ Recommended Action } \\
\hline $\begin{array}{l}\text { Objectives, Independence, Powers, Transparency and } \\
\text { Cooperation (CP1) }\end{array}$ & $\begin{array}{l}\text { (i) Make more effective use of SD resources. (ii) Avoid } \\
\text { needless exposure for the BOM through "Approvals in } \\
\text { Principle." (iii) The criteria specified in the BOMA to } \\
\text { be met by appointees to the posts of governor and } \\
\text { deputy governors should more closely track those for } \\
\text { other directors. (iv) Proclaim remaining portions of BA. } \\
\text { (v) Limit holdings in "equity funds" (see CP 5). } \\
\text { (vi) Revise drafting of guidelines to a more legally } \\
\text { rigorous style to enhance their enforceability. } \\
\text { (vii) Bring MOU with FSC into force. }\end{array}$ \\
\hline Permissible Activities (CP 2) & \begin{tabular}{l} 
Provide an expanded definition of "banking business." \\
\hline
\end{tabular}
\end{tabular}




\begin{tabular}{|c|c|}
\hline Reference Principle & Recommended Action \\
\hline Licensing criteria (CP3) & $\begin{array}{l}\text { (i) Avoid needless exposure for the BOM by } \\
\text { "Approvals in Principle." (ii) SD employees to have a } \\
\text { check-list to track receipt of required documentation. } \\
\text { (iii)Allow above "significant interest" to an } \\
\text { incorporator until bank's capital is a threshold size. }\end{array}$ \\
\hline Transfer of Significant Ownership (CP4) & $\begin{array}{l}\text { Set in place a reporting mechanism for disclosure of } \\
\text { beneficial "significant" ownership interests. }\end{array}$ \\
\hline Major Acquisitions (CP 5) & $\begin{array}{l}\text { Provide for BOM notification and approval of } \\
\text { investment in "equity funds." }\end{array}$ \\
\hline Capital adequacy (CP6) & $\begin{array}{l}\text { Expand "consolidated" capital adequacy computation } \\
\text { beyond the two large domestic banks. }\end{array}$ \\
\hline Risk management Process (CP 7) & $\begin{array}{l}\text { Provide detailed guidance for examiners to assess } \\
\text { compliance with new Guideline after September } 2007 .\end{array}$ \\
\hline \multicolumn{2}{|l|}{ Credit risk (CP8) } \\
\hline Problem assets, Provisions and Reserves (CP 9) & $\begin{array}{l}\text { Implement quarterly reporting of NPLs and } \\
\text { provisioning. }\end{array}$ \\
\hline Large Exposure Limits (CP10) & Monitor geographic exposure. \\
\hline Exposures to Related Parties (CP 11) & $\begin{array}{l}\text { (i) Impose a specific requirement that related party } \\
\text { exposures be collateralized or deducted from capital } \\
\text { when assessing capital adequacy. (ii) Receive quarterly } \\
\text { detailed reporting on related party transactions. } \\
\text { (iii) Cease supervisory approval of exemptions. }\end{array}$ \\
\hline Country and Transfer Risks (CP 12) & Issue guidance on managing risks \\
\hline Market Risk (CP 13) & $\begin{array}{l}\text { Provide detailed guidance for examiners to assess } \\
\text { compliance with new Guideline after September } 2007 .\end{array}$ \\
\hline Liquidity Risk (CP 14) & $\begin{array}{l}\text { Provide for reporting of "gap analysis" by banks rather } \\
\text { than by transposition of bank data by SD examiners. }\end{array}$ \\
\hline Operational Risk (CP 15) & $\begin{array}{l}\text { Provide detailed guidance to examiners for assessment } \\
\text { of adherence to Guideline. }\end{array}$ \\
\hline \begin{tabular}{|l} 
Interest Rate Risk in the Banking Book (CP 16) \\
\end{tabular} & $\begin{array}{l}\text { Provide detailed guidance for examiners to assess } \\
\text { compliance with new Guideline after September } 2007 .\end{array}$ \\
\hline \multicolumn{2}{|l|}{ Internal Control and Audit (CP17) } \\
\hline \multicolumn{2}{|l|}{ Abuse of Financial Services (CP18) } \\
\hline Supervisory Approach (CP 19) & $\begin{array}{l}\text { (i)Acquire effective IT platform for off-site data } \\
\text { manipulation. (ii) Avoid use of personnel in peripheral } \\
\text { tasks. }\end{array}$ \\
\hline Supervisory Techniques (CP 20) & $\begin{array}{l}\text { (i) Meet with banks' boards at start of bank year; } \\
\text { (ii) Meet Audit Committee to receive presentation on } \\
\text { matters raised in previous audit. }\end{array}$ \\
\hline Supervisory Reporting (CP 21) & $\begin{array}{l}\text { Increase frequency of data on asset quality and loan } \\
\text { loss provisioning. Include "gap analysis" in liquidity } \\
\text { reporting. Prepare for reporting of interest-rate risk } \\
\text { (September 2007). }\end{array}$ \\
\hline \multicolumn{2}{|l|}{ Accounting and Disclosure (CP 22) } \\
\hline Supervisors' Corrective and Remedial Powers (CP 23) & $\begin{array}{l}\text { (i) Revise intervention model to provide for rapid exit } \\
\text { of a failed institution. (ii) Revise procedures/work } \\
\text { methods/use of resources to avoid lengthy delays in } \\
\text { presentation of examination report. }\end{array}$ \\
\hline
\end{tabular}




\begin{tabular}{|l|l|}
\hline \multicolumn{1}{|c|}{ Reference Principle } & \multicolumn{1}{c|}{ Recommended Action } \\
\hline Consolidated Supervision (CP 24) & Bring MOU with FSC into force. \\
\hline Home-Host relationships (CP 25) & $\begin{array}{l}\text { Enhance cooperation and information exchange with } \\
\text { overseas supervisors to, inter alia, benefit from } \\
\text { consolidated supervision. }\end{array}$ \\
\hline
\end{tabular}

\section{Authorities' response}

The Bank is in general agreement with the assessment. However, it is noticed that in the case of some core principles, the assessment does not provide full recognition of the continuing efforts to enhance the regulatory and supervisory framework. In some areas, such as licensing criteria and supervisory reporting, much progress has been made but the Mission has not given due recognition in the assessment process. The Bank therefore considers certain parts of the assessment too harsh, given the significant improvements in our framework made with a view to adhering to best international practices. 